\title{
Transfection of human insulin-like growth factor-binding protein 3 gene inhibits cell growth and tumorigenicity: a cell culture model for lung cancer
}

\author{
R Hochscheid, G Jaques and B Wegmann ${ }^{1}$ \\ Department of Internal Medicine, Division of Hematology/Oncology, Philipps-University, Baldingerstrasse, D-35033 Marburg, Germany \\ ${ }^{1}$ Department of Internal Medicine, University Hospital, Zurich, Switzerland \\ (Requests for offprints should be addressed to G Jaques, Klinikum der Philipps-Universität, Zentrum für Innere Medizin, Baldingerstraße, D-35033 Marburg, \\ Germany; Email: jaquesg@mailer.uni-marburg.de)
}

\begin{abstract}
IGF-I and IGF-II are potent mitogens, postulated to exert autocrine/paracrine effects on growth regulation in human lung cancer. Their proliferative effects are modulated by IGF-binding proteins (IGFBPs), which are found in conditioned medium $(\mathrm{CM})$ of lung cancer cell lines. The biological role of the IGFBPs, which are ontogenetically and hormonally regulated, is not fully understood. Both inhibitory and stimulatory effects on cell growth have been demonstrated. Exogenous IGFBP-3 has been consistently shown to block IGF action, inhibiting cell growth in vitro. In order to evaluate the action of endogenously produced IGFBP-3 on cell growth in lung cancer, we stably transfected the non-small cell lung cancer cell line NCI$\mathrm{H} 23$ with human IGFBP-3 cDNA (resulting in NCI-H23 pOPI3/BP-3) or with the vector pOPI3CAT as control (resulting in NCI-H23 pOPI3CAT). RT-PCR confirmed expression of IGFBP-3-specific mRNA in NCI$\mathrm{H} 23$ pOPI3/BP-3, but not in NCI-H23 or NCI-H23 pOPI3CAT. Western ligand blot and Western immuno-
\end{abstract}

blot analysis of CMs yielded strong signals of the characteristic 40-44 kDa human IGFBP-3 protein in NCI-H23 pOPI3/BP-3. An IGFBP-3 ELISA demonstrated a 20fold increase in IGFBP-3 protein expression in NCI-H23 pOPI3/BP-3 as compared with NCI-H23. The growth of NCI-H23 pOPI3/BP-3 in serum-containing medium was significantly slower $(1 \cdot 7$-fold $)$ than that of NCI-H23 or the vector-transfected control NCI-H23 pOPI3CAT. While the proliferation rate of parental and vectortransfected cells could be stimulated by IGF-I, IGF-II, IGF-I analog Long $\mathrm{R}^{3}$ IGF-I or insulin, that of NCI-H23 pOPI3/BP-3 could not. Xenotransplantation in nude mice resulted in marked tumor growth after the injection of NCI-H23 or NCI-H23 pOPI3CAT, but absent or minimal growth for the IGFBP-3-transfected cell line.

These data suggest that IGFBP-3 is a potent inhibitor of cell growth in human lung cancer cell lines and may impair tumorigenicity in vivo.

Journal of Endocrinology (2000) 166, 553-563

\section{Introduction}

The insulin-like growth factors (IGFs)-I and -II are important mitogens for many cell types and act in an autocrine/paracrine manner (Jaques et al. 1988, Daughaday 1990). Their mitogenic effects are specifically mediated by binding to the cell surface IGF-I receptor, although both molecules also bind to the IGF-II receptor (King et al. 1980, Krull et al. 1983). Furthermore, IGF-I and IGF-II interact with high affinity with a family of extracellular soluble IGF-binding proteins (IGFBPs), of which six distinct members (IGFBP-1 to IGFBP-6) have been identified and cloned to date (Shimasaki \& Ling 1991). The physiological role of the IGFBPs is not yet clear but probably depends on cell type and growth milieu. The balance of affinities between the interaction of the IGFs with their receptors on the one hand and their binding proteins on the other regulates the function and bioavailability of IGF-I and IGF-II in an inhibitory or stimulatory way (Baxter \& Martin 1989). IGFBP-3 is the major binding protein in human plasma, where it is found as part of a $150 \mathrm{kDa}$ complex including an acid-labile subunit and an IGF molecule (Baxter 1988).

We and others have shown that IGF-I and IGF-II stimulate the proliferation of both small cell lung cancer (SCLC) and non-small cell lung cancer (NSCLC) cell lines, which each express IGF receptors and secrete IGFBPs of different molecular weights into their culture medium (Jaques et al. 1988, 1992, Kiefer et al. 1991, Reeve et al. 1992, Wegmann et al. 1993). In vitro experiments in other cell types, however, have demonstrated that IGFBP-3 can stimulate as well as inhibit the mitogenic effects of IGFs (Elgin et al. 1987, Conover et al. 1990). 
It appears that IGFBP-3 inhibits the cellular growth of certain cell lines by an IGF-I receptor-independent pathway and a specific IGFBP-3 receptor has been postulated (Cohen et al. 1993, Oh et al. 1993, Lalou et al. 1996, Leal et al. 1997). Structural analysis has identified a nuclear localization signal in IGFBP-3 (Radulescu 1994). Therefore, it was hypothesized that IGFBP-3 may act as a nuclear tumor suppressor, similar to retinoblastoma protein (RB), and interact with RB-binding proteins. We and others have recently demonstrated the nuclear localization of IGFBP-3 in the NSCLC cell line A549 and in the keratinocyte cell line $\mathrm{HaCaT}$ by immunocytochemistry with an anti-human IGFBP-3 antibody (Jaques et al. 1997, Wraight et al. 1997).

To examine the effect of endogenous IGFBP-3 on lung cancer cell growth, we cloned human IGFBP-3 cDNA into a mammalian expression vector containing the RSVLTR promoter and used this construct to stably transfect the NSCLC cell line NCI-H23.

\section{Materials and Methods}

\section{Cell line and cell culture}

The established human NSCLC adenocarcinoma cell line NCI-H23 (Gazdar 1986), donated by Drs A F Gazdar and J Minna, National Cancer Institute (Bethesda, MD, USA) was used in this study. NCI-H23 was cultured in RPMI 1640 medium (Life Technologies Europe, Paisley, Strathclyde, UK) supplemented with $2 \mathrm{mM}$ L-glutamine and $10 \%$ fetal calf serum (Life Technologies), designated $\mathrm{R} 10$, in a humidified atmosphere of $95 \%$ air and $5 \% \mathrm{CO}_{2}$ at $37^{\circ} \mathrm{C}$. Transfected cells were grown in R10 supplemented with $300 \mu \mathrm{g} / \mathrm{ml}$ of the antibiotic geneticin (G418) (Life Technologies). Stable transfectants were generated from pOPI3CAT- and pOPI3/BP-3-transfected NCI$\mathrm{H} 23$ cells and were designated NCI-H23 pOPI3CAT and NCI-H23 pOPI3/BP-3 respectively.

Western immunoblot and Western ligand blots were carried out under serum-free conditions using RPMI 1640 supplemented with $5 \cdot 2 \mathrm{ng} / \mathrm{ml}$ sodium selenite and $5 \mu \mathrm{g} / \mathrm{ml} \mathrm{98 \%} \mathrm{iron-free} \mathrm{human} \mathrm{transferrin} \mathrm{(Sigma,}$ Deisenhofen, Germany), designated ST medium.

For the tetrazolium-based compound (MTT) and cloning assays, cells were grown in RPMI 1640 supplemented with $0 \cdot 25 \%$ BSA (Sigma), designated R0 medium.

\section{Expression vector and transfection}

The mammalian expression vector pOPI3CAT (Stratagene, Heidelberg, Germany), which contains the neomycinselection gene conferring resistance to G418, the RSVLTR promoter, a bacterial selection AMP gene and a NotI site for insertion, was used to generate a construct containing human IGFBP-3 cDNA. After NotI digestion and conse- quent loss of the CAT gene, the vector was designated pOPI3. The EcoRI/NotI IGFBP-3 cDNA fragment $(1.5 \mathrm{~kb})$, digested and isolated from Bluescript II $\mathrm{KS}(+)$, contains the full-length coding sequence of human IGFBP-3 cDNA (donated by Dr W I Wood, Genentech, Inc., South San Francisco, CA, USA). Transfection was achieved by means of the Transfectam protocol according to the manufacturer's (Sepracor, Idstein, Germany) specifications. Stable transfectants were selected by the addition of G418 to the growth medium. Clones were derived from single stably transfected cells by serial dilution.

\section{Preparation of total RNA}

Adherently growing cells were harvested in their logarithmic growth phase using EDTA $(0.02 \%$ in PBS without $\left.\mathrm{Ca}^{2+} / \mathrm{Mg}^{2+}\right)$ and washed in PBS. Cells were dissolved in $4 \mathrm{M}$ guanidinium thiocyanate, $25 \mathrm{mM}$ sodium citrate $\mathrm{pH} \quad 7 \cdot 0, \quad 0 \cdot 5 \% \quad$ N-lauryl sarcosine and $100 \mathrm{mM}$ $\beta$-mercaptoethanol. After addition of $100 \mathrm{mM}$ sodium acetate and equal volumes of phenol and chloroform, the samples were kept on ice for $15 \mathrm{~min}$. After centrifugation $\left(20 \mathrm{~min}, 4{ }^{\circ} \mathrm{C} 20000 \mathrm{~g}\right)$ the aqueous phase was phenol/ chloroform extracted once again and the RNA was precipitated by addition of three volumes of ethanol.

\section{$R T-P C R$}

Four micrograms total RNA were reverse transcribed with Superscript-RT (Life Technologies). Successful transfection and integration of pOPI3CAT and pOPI3/BP-3 was tested with a vector-specific primer pair $\left(5^{\prime}\right.$-primer: CTC CTC AGG GAT CCT AAT TGT TTG TG; $3^{\prime}$-primer: TCT CCT TCC GTG TTT CAG TTC TTA AG). The following primer pair was used for the specific amplification of IGFBP-3 cDNAs: 5'-primer: GCT CTG CGT CAA CGC TAG TG; 3'-primer: GCT TCC TGC CTT TGG AAG GG. This primer pair amplifies a 468 bp sequence of IGFBP-3. The $\varphi$ X174/HaeIII marker (Life Technologies) was used as a DNA marker for agarose gel electrophoresis.

\section{Preparation of conditioned medium (CM)}

To prepare CM for use in the IGFBP-3 ELISA, $2.5 \times 10^{4}$ cells $/ \mathrm{ml}$ were seeded in R10 medium in six-well tissue culture dishes (Greiner, Nürtingen, Germany). At 3 and 5 days the supernatants were collected, cleared of cell debris by centrifugation at $1000 \mathrm{~g}$ and stored at $-20^{\circ} \mathrm{C}$ until analyzed. Viable cells were counted after trypan blue staining to calculate cell density.

To prepare CM for use in Western immunoblot and Western ligand blot, $4 \times 10^{4}$ cells $/ \mathrm{ml}$ were plated in $\mathrm{T}-150$ tissue culture flasks (Greiner) in R10. After $24 \mathrm{~h}$, adherently growing cells were washed with RPMI 1640 and the medium was changed to a serum-free ST 
medium. Cells were counted and the CMs were harvested at the indicated times and treated as described above.

\section{Western ligand blot}

Ligand blotting of CM was performed as described previously (Hossenlopp et al. 1986). In brief, samples of CM were concentrated by precipitation with trichloroacetic acid (7\% final concentration). The precipitates were dissolved in $25 \mu \mathrm{l}$ gel sample buffer, boiled for $2 \mathrm{~min}$ and separated by electrophoresis on a 12\% SDS-PAGE gel under non-reducing conditions. The proteins were transferred to an Immobilon-P membrane (Millipore, Eschborn, Germany). After the transfer of proteins, the membranes were incubated overnight at $4{ }^{\circ} \mathrm{C}$ in Trisbuffered saline (TBS; $10 \mathrm{mM}$ and $150 \mathrm{mM} \mathrm{NaCl}, \mathrm{pH} 7 \cdot 4$ ) containing 3\% BSA. IGFBPs were detected by incubating the blots with 200000 c.p.m. ${ }^{125}$ I-IGF-II (Amersham, Braunschweig, Germany) in $50 \mathrm{mM}$ sodium phosphate buffer, $\mathrm{pH} 6 \cdot 5$, for $4 \mathrm{~h}$ at room temperature. The blots were rinsed three times in PBS, once in PBS containing $0.5 \%$ Nonidet P-40, and once again in detergent-free PBS. The dried blots were autoradiographed for 3-5 days at $-70{ }^{\circ} \mathrm{C}$.

\section{Western immunoblot}

The Immobilon-P membranes were blocked with TBS, $\mathrm{pH} 7 \cdot 4$, containing 3\% BSA for $2 \mathrm{~h}$ at room temperature and then incubated overnight at $4{ }^{\circ} \mathrm{C}$ with diluted IGFBP-3 antiserum (Immundiagnostik, Bensheim, Germany) in TBS-3\% BSA. The IGFBP-3 antiserum was used at a dilution of 1:1000. The membranes were washed three times with TBS-0.1\% Nonidet P-40 and an additional three times with TBS. The proteins were detected using a biotinylated anti-rabbit antibody (Amersham) diluted 1:400 in PBS, 0.1\% Tween-20, and 0.25\% BSA. The enhanced chemiluminescence (ECL) peroxidase substrate (Amersham) was applied according to the manufacturer's instructions and the membrane was exposed briefly to autoradiographic film.

\section{IGFBP-3 ELISA}

For determination of IGFBP-3 concentrations the ACTIVE IGFBP-3 ELISA (DSL, Sinsheim, Germany), an enzymatic 'two-step sandwich' immunoassay, was used. A polyclonal antibody to IGFBP-3 was pre-bound to the surface of a microtiter plate. After incubation with the CM a second polyclonal anti-IGFBP-3 was added, which was labeled with horseradish peroxidase. The microtiter plates were then incubated with tetra-methylbenzidine. Addition of sulfuric acid stopped the color reaction and the absorbance was measured at dual wavelengths of 450 and $620 \mathrm{~nm}$.

\section{Growth kinetics}

Cells were seeded in R10 medium at a concentration of $5 \times 10^{3}$ cells $/ \mathrm{ml}$ in $24-$ well tissue culture plates (Greiner). Starting at day 3 , the cells were harvested daily using EDTA $\left(0.02 \%\right.$ in PBS without $\left.\mathrm{Ca}^{2+} / \mathrm{Mg}^{2+}\right)$, stained with trypan blue and counted in a Neubauer chamber. Cell number was assayed in quadruplicate and experiments were repeated three times. The mean cell number was plotted as a function of time and the doubling time was calculated during the logarithmic growth phase.

\section{MTT assay}

The colorimetric assay is based on the ability of viable cells to reduce MTT. Under defined conditions the cell number is directly proportional to MTT reduction (Nakanishi et al. 1988), whereby a doubling of optical density indicates a doubling of cell number. IGF-I, IGF-II (Bachem Chemicals, Bubendorf, Switzerland), the IGF-I analog Long $\mathrm{R}^{3}$ IGF-I (DSL) and insulin (Sigma) were each diluted in R0, mixed with $1 \times 10^{4}$ cells/well and plated in 96-well tissue culture plates (Nunc, Wiesbaden, Germany). The final concentration of the IGFs and the IGF analog was between 0.001 and $10 \mathrm{nM}$. The concentration of insulin was between 0.07 and $7000 \mathrm{ng} / \mathrm{ml}$. Four days later $10 \mu \mathrm{l}$ MTT $(2.5 \mathrm{mg} / \mathrm{ml}$, Sigma $)$ were added to each well and incubated at $37^{\circ} \mathrm{C}$ for $1 \mathrm{~h}$. The plates were then centrifuged at $150 \mathrm{~g}$ for $5 \mathrm{~min}$ and the media were removed. The MTT product was solubilized in $100 \mu \mathrm{l}$ dimethylsulfoxide and absorbance was measured using an automated microplate reader at a wavelength of $560 \mathrm{~nm}$. Experiments were performed in eight replicates and the study was repeated three times.

\section{Apoptosis assays}

Apoptosis was evaluated by using a TUNEL assay (apopDETEK, Enzo Diagnostics, New York, NY, USA) and a cell-death detection ELISA (Boehringer, Mannheim, Germany). Cells were seeded in R10 medium at a concentration of $5 \times 10^{4} / \mathrm{ml}$ and allowed to attach overnight. Floating and attached cells were pooled and cytospins were prepared, dried at room temperature, fixed with acetone and further stained according to the manufacturer's instructions. The slides were reacted with diaminobenzidine solution. For quantification four fields at $200 \times$ magnification from each slide were selected, stained cells were counted in a phase contrast microscope and are given as percent of total cell number.

The cell-death detection ELISA was also applied according to the manufacturer's instructions. The ELISA is based on a quantitative sandwich enzyme immunoassay using mouse monoclonal antibodies directed against DNA and histones. Using this assay, the mono- and 


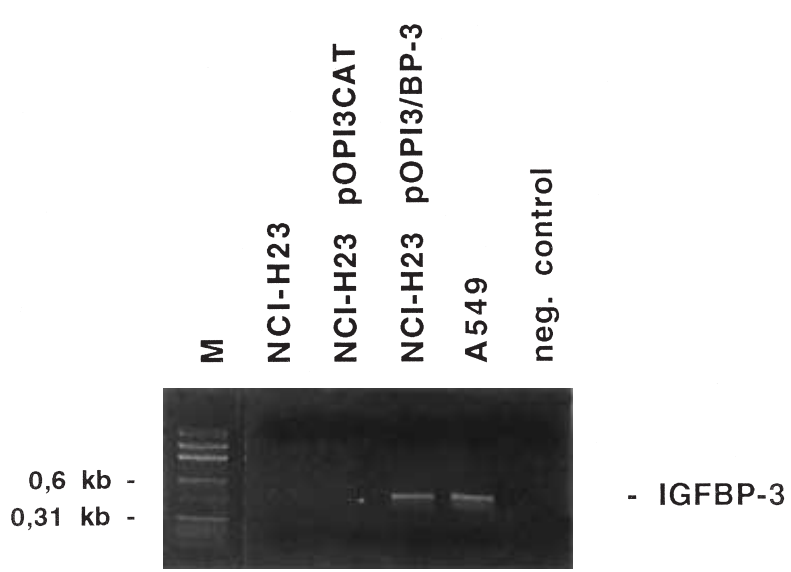

Figure 1 Ethidium bromide-stained 1.5\% agarose gel showing RT-PCR with cDNAs of $\mathrm{NCl}-\mathrm{H} 23$ and its transfectants after 35 cycles. The IGFBP-3-specific primer pair amplified a $468 \mathrm{bp}$ transcript in the parental cell line and in the $\mathrm{NCl}-\mathrm{H} 23 \mathrm{pOPI} / \mathrm{BP}-3$ transfectant cell line. In contrast, in the $\mathrm{NCl}-\mathrm{H} 23$ pOPI3CAT transfectant no amplification of IGFBP-3 could be observed. The NSCLC cell line A549 served as positive control and $\varphi$ X174/HaellI as marker (M).

oligonucleosomes were specifically determined in the cytoplasmic fraction of cell lysates from $10^{6}$ cells.

\section{Xenotransplantation}

NMRI athymic nude mice $(\mathrm{nu} / \mathrm{nu})$ were kept in macrolon cages in a laminar flow unit at $27^{\circ} \mathrm{C}$ and $60-70 \%$ relative humidity. Viable logarithmically growing cells $\left(1 \times 10^{6}\right)(\mathrm{NCI}-\mathrm{H} 23$, NCI-H23 pOPI3CAT or NCI$\mathrm{H} 23$ pOPI3/BP-3) were suspended in $200 \mu \mathrm{PBS}$ and then injected s.c. Four mice were inoculated for each cell line. Tumor growth was measured with sliding calipers every 2-4 days. The experiment was repeated twice. Mice were maintained in accordance with the NIH Guide for the Care and Use of Laboratory Animals.

\section{Results}

Stable transfection and expression of recombinant IGFBP-3

A full-length cDNA of IGFBP-3 was cloned into the mammalian expression vector pOPI3. The NSCLC cell line NCI-H23 was transfected with the IGFBP-3containing expression vector (NCI-H23 pOPI3/BP-3) and, as control, with the vector alone (NCI-H23 pOPI3 CAT) as described in Materials and Methods. Single cell colonies were isolated and confirmed using RT-PCR with a vector-specific primer pair (data not shown). The presence of endogenous and recombinant IGFBP-3 mRNA was verified using an IGFBP-3-specific primer pair. IGFBP-3 expression in the adenocarcinoma cell line A549 provided a positive control. IGFBP-3 expression was

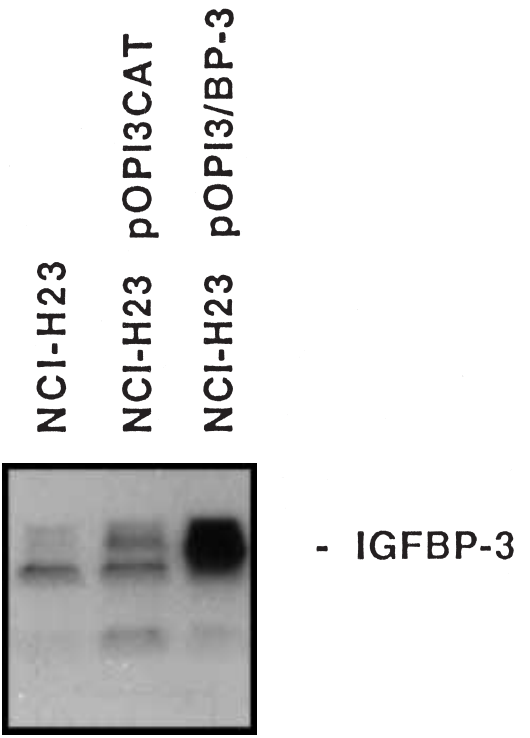

Figure 2 Western ligand blot of $\mathrm{CM}$ from $\mathrm{NCl}-\mathrm{H} 23, \mathrm{NCl}-\mathrm{H} 23$ pOPI3CAT and $\mathrm{NCl}-\mathrm{H} 23$ pOPI3/BP-3; $4 \times 10^{4}$ cells $/ \mathrm{ml}$ were plated in serum-containing medium (R10). After $24 \mathrm{~h}$, adherently growing cells were washed and cultured in ST medium for 4 days. Cells were counted and the CMs were harvested and equilibrated to the cell number. Precipitated protein from equivalent volumes of $\mathrm{CM}$ was blotted to Immobilon-P membrane and was probed with ${ }^{125}$ I-IGF-II. In CM from NCl-H23 pOPI3/BP-3 a strong signal representing a $40-44 \mathrm{kDa}$ form of IGFBP was detectable, while in $\mathrm{NCl}-\mathrm{H} 23$ and $\mathrm{NCl}-\mathrm{H} 23$ pOPI3CAT only weak signals were observed. In all three cell lines weak bands of approximately 36 and $26 \mathrm{kDa}$ were detectable.

detectable in NCI-H23 pOPI3/BP-3 cells but not in the parental cell line or the vector-transfected cells (Fig. 1).

\section{Identification and quantification of IGFBP-3 in CM}

Since IGFBP-3-expressing cell lines have been shown to secrete IGFBPs into the CM, we were interested to analyze the CM of our transfected cell lines. Secretion of IGFBP-3 into CM by NCI-H23, NCI-H23 pOPI3CAT and NCI-H23 pOPI3/BP-3 was evaluated by Western ligand blot (Fig. 2) and Western immunoblot (Fig. 3). NCI-H23 pOPI3/BP-3 predominantly secreted a 40$44 \mathrm{kDa}$ form of IGFBP, which showed only a weak signal in NCI-H23 and NCI-H23 pOPI3CAT. In addition, weak bands of approximately 36 and $26 \mathrm{kDa}$ were detectable in all three cell lines.

To determine whether the $40-44 \mathrm{kDa}$ band in the Western ligand blot corresponded specifically to IGFBP-3, Western immunoblotting was performed using antisera specific for IGFBP-3. In NCI-H23 pOPI3/BP-3 a strong IGFBP-3-specific signal of approximately $43 \mathrm{kDa}$ was detectable, while in CMs of NCI-H23 and NCI-H23 pOPI3CAT only weak signals were obtained (Fig. 3). 


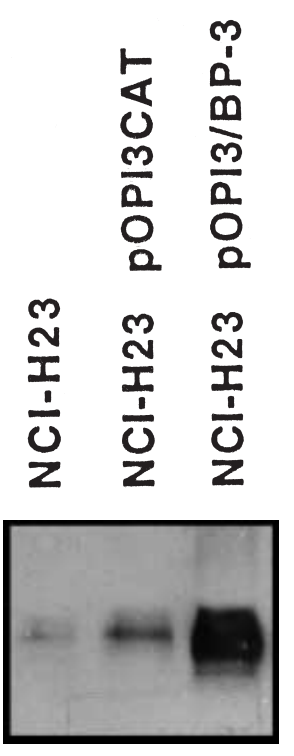

- IGFBP-3

$30 \mathrm{kD}$ -

Figure 3 Western immunoblot of $\mathrm{CMs}$ from $\mathrm{NCl}-\mathrm{H} 23$ and its transfectants; $4 \times 10^{4}$ cells $/ \mathrm{ml}$ were plated in R10. After $24 \mathrm{~h}$ adherently growing cells were washed and cultured in ST medium for 4 days. Cells were counted and the CMs were harvested and equilibrated to the cell number. Precipitated protein from equivalent volumes of $\mathrm{CM}$ was blotted to Immobilon-P membrane. The membrane was incubated with an IGFBP-3-specific antiserum, which was visualized with an ECL peroxidase substrate. The immunoblot of the $\mathrm{CM}$ from $\mathrm{NCl}-\mathrm{H} 23$ pOPI3/BP-3 showed a strong IGFBP-3-specific signal, while in $\mathrm{CMs}$ from $\mathrm{NCl}-\mathrm{H} 23$ and $\mathrm{NCl}-\mathrm{H} 23 \mathrm{pOPI} 3 \mathrm{CAT}$ only weak signals were obtained.
To quantify the amount of IGFBP-3 protein present, we used an IGFBP-3 enzyme immunoassay. The results were calculated for $1 \times 10^{5}$ viable cells (Fig. 4 ). In the CM of NCI-H23 pOPI3/BP-3 the IGFBP-3 concentration was 20 -fold higher $(8 \cdot 1 \mathrm{ng} / \mathrm{ml})$ than in the parental cell line NCI-H23 (0.4 ng/ml).

\section{Proliferation and apoptosis in serum-containing medium}

In order to compare the growth of the IGFBP-3transfected cells with the parental cell line and vectortransfected cell line, $5 \times 10^{3}$ cells $/ \mathrm{ml}$ were plated in R10 and viable cells were counted daily, starting on day 3 . Figure 5A shows the growth curves of the three cell lines. The proliferation rate of NCI-H23 pOPI3/BP-3 was considerably slower than that of NCI-H23 or NCIH23 pOPI3CAT. While NCI-H23 and NCI-H23 pOPI3CAT reached their saturation density on day 8 , the IGFBP-3-transfected cells started growing exponentially between day 9 and 12. In all cell lines growth arrested at a cell density between $7 \times 10^{5}$ and $1 \times 10^{6}$ cells. The doubling time of NCI-H23 pOPI3/BP-3 was $1 \cdot 7$-fold slower than that of NCI-H23 and $1 \cdot 5$-fold slower than that of NCI-H23 pOPI3CAT (Fig. 5B).

Induction of apoptosis appears to be a major mechanism by which IGFBP-3-dependent growth inhibition occurs (Rajah et al. 1997). We conducted a TUNEL assay and a cell-death detection ELISA to evaluate the rate of apoptosis in all three cell lines. Under basal conditions in

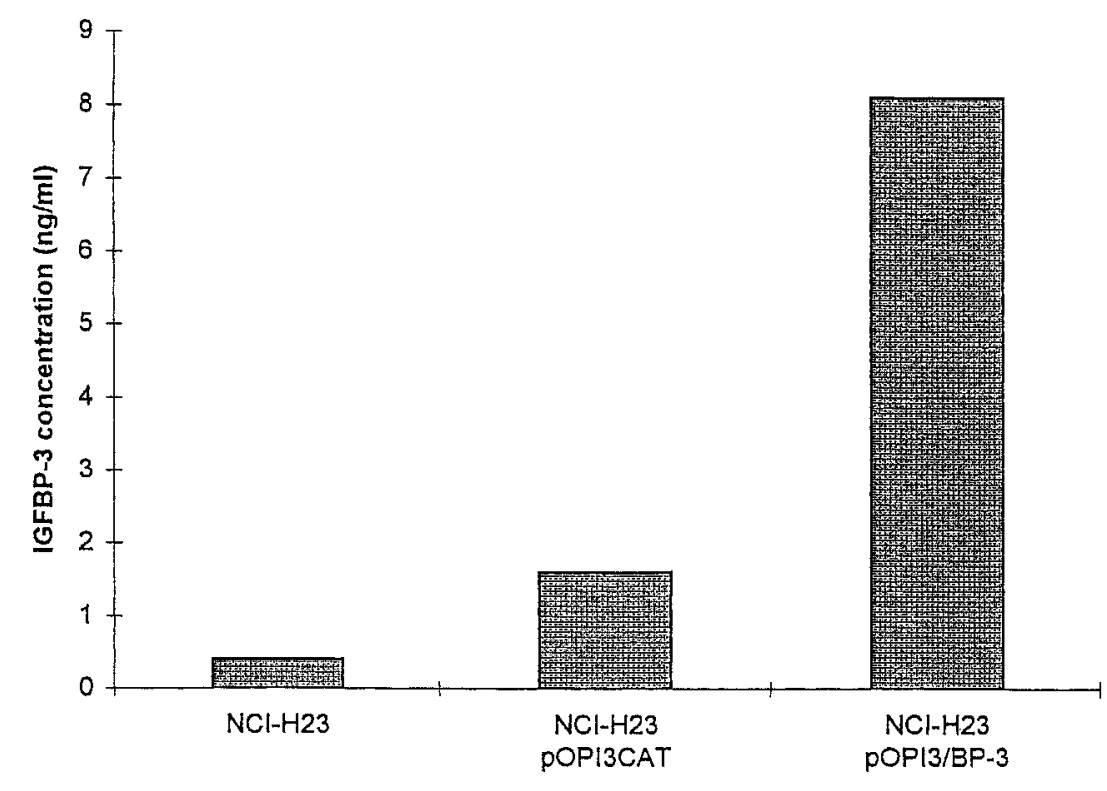

Figure 4 IGFBP-3 ELISA for CM from NCl-H23, NCl-H23 pOPI3CAT and $\mathrm{NCl}-\mathrm{H} 23$ pOPI3/BP-3. The graph shows the concentration of IGFBP-3 from CM harvested after 5 days and calculated for $1 \times 10^{5}$ viable cells. In the $\mathrm{CM}$ from $\mathrm{NCl}-\mathrm{H} 23 \mathrm{pOPI} / \mathrm{BP}-3$ the IGFBP-3 concentration was 20 -fold greater than with the parental cell line and 5 -fold greater than with the $\mathrm{NCl}-\mathrm{H} 23$ pOPI3CAT transfectant. 

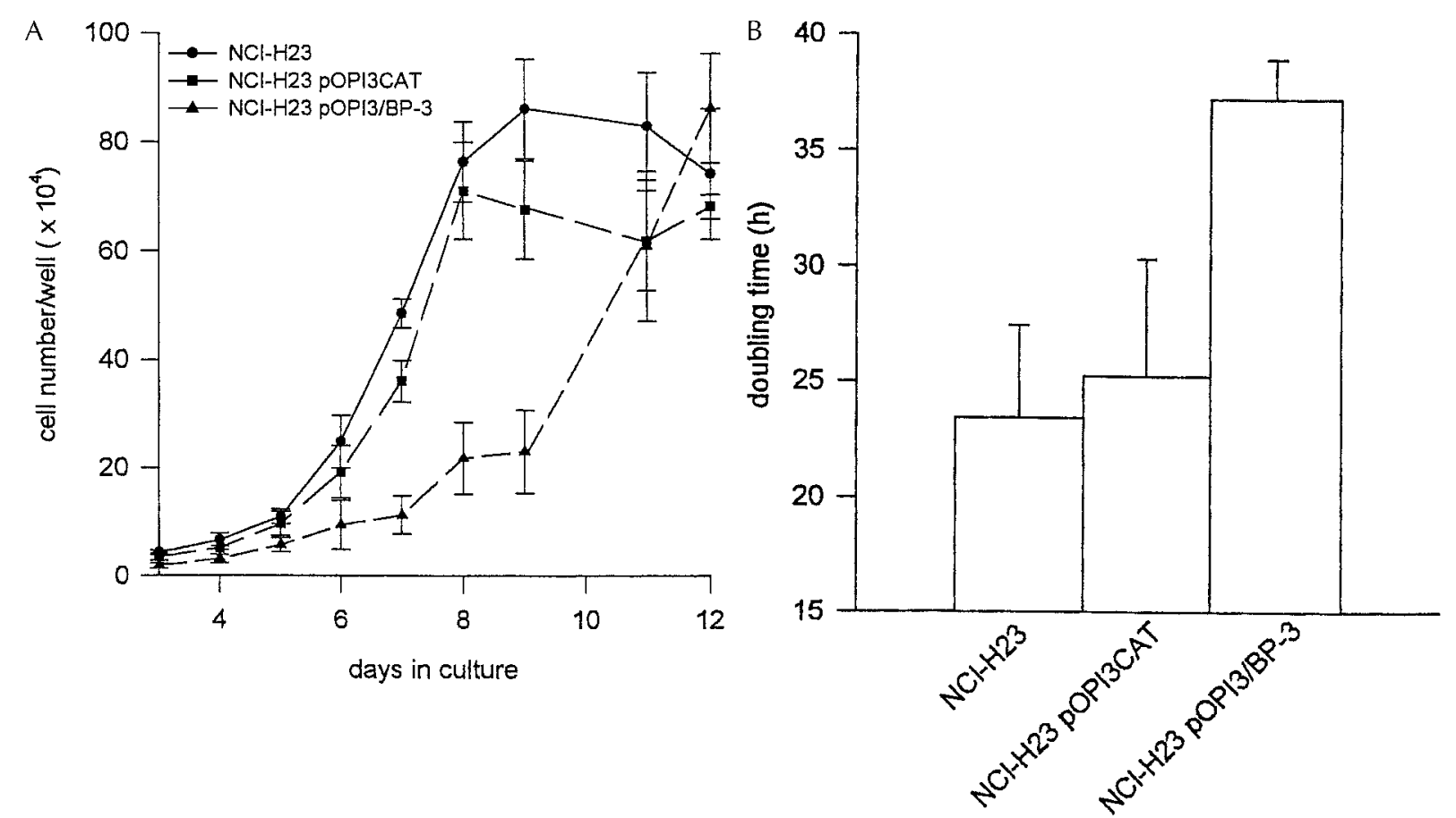

Figure 5 Growth kinetics for $\mathrm{NCl}-\mathrm{H} 23, \mathrm{NCl}-\mathrm{H} 23$ pOPI3CAT and $\mathrm{NCl}-\mathrm{H} 23$ pOPI3/BP-3 in serum-containing medium (R10). (A) Cells were seeded at a concentration of $5 \times 10^{3} / \mathrm{ml}$ and counted daily from day 3 . The values shown are means \pm S.D., calculated from replicates of four. The growth rate of $\mathrm{NCl}-\mathrm{H} 23$ pOPI3/BP-3 was significantly slower than that of the parental cell line $\mathrm{NCl}-\mathrm{H} 23$ and the transfectant $\mathrm{NCl}-\mathrm{H} 23$ pOPI3CAT. (B) The doubling time was calculated during the logarithmic growth phase. The values shown are means \pm S.D., calculated from three experiments. The doubling times of $\mathrm{NCl}-\mathrm{H} 23, \mathrm{NCl}-\mathrm{H} 23 \mathrm{pOPI} 3 \mathrm{CAT}$ and for $\mathrm{NCl}-\mathrm{H} 23$ pOPI3/BP-3 were 23, 25 and 37 h respectively.

supplemented medium no difference between the cell lines was found. The rate of apoptosis for all three cell lines was in the range of $6 \cdot 5$ to $7 \cdot 6 \%$ (data not shown).

\section{Effects of IGF-I, IGF-II, IGF analog Long $R^{3}$ IGF-I or} insulin on the growth of NCI-H23 and the transfected cell lines

Cell proliferation during IGF-I and IGF-II stimulation was investigated using an MTT assay. Figure 6 shows the growth curves under the stimulation of IGF-I (Fig. 6A) and IGF-II (Fig. 6B). IGF-I and IGF-II were mitogenic for NCI-H23 and NCI-H23 pOPI3CAT at nanomolar concentrations. The growth inhibitory effect on IGFBP3-transfected cells remained constant despite treatment with IGF-I or IGF-II. IGF-concentrations over $70 \mathrm{ng} / \mathrm{ml}$ did not increase the mitogenic effect for any of the three cell lines (data not shown). To investigate a possible IGF-independent growth inhibitory effect of IGFBP-3 in NCI-H23 pOPI3/BP-3, we stimulated the cells with IGF-I, insulin (Fig. 7A, B) or with Long $\mathrm{R}^{3}$ IGF-I (Fig. 7C), an IGF-I analog that exhibits markedly reduced binding to IGFBPs. The growth inhibitory effect in NCI-H23 pOPI3/BP-3 could not be countered by insulin or the IGF-I analog. In contrast, both substances effectively stimulated the cell growth of NCI-H23 and NCIH23 pOPI3CAT.

\section{Tumor formation in athymic nude mice}

Tumorigenicity was studied by xenotransplantation experiments using athymic nude mice. All animals injected with NCI-H23 or NCI-H23 pOPI3CAT cells developed tumors, of which the size increased progressively. In contrast, no or only small tumors developed in mice injected with NCI-H23 pOPI3/BP-3. Figure 8 shows tumor sizes on days 7 and 36 . The two tumor-free mice were observed for a further 2 months and no tumor growth was observed up to that time-point.

\section{Discussion}

This study has demonstrated that overexpression of IGFBP-3 in an NSCLC cell line inhibits the cell proliferation rate in vitro and results in reduced tumor growth in vivo. This effect could not be countered by stimulation with the mitogens IGF-I and IGF-II or insulin. 

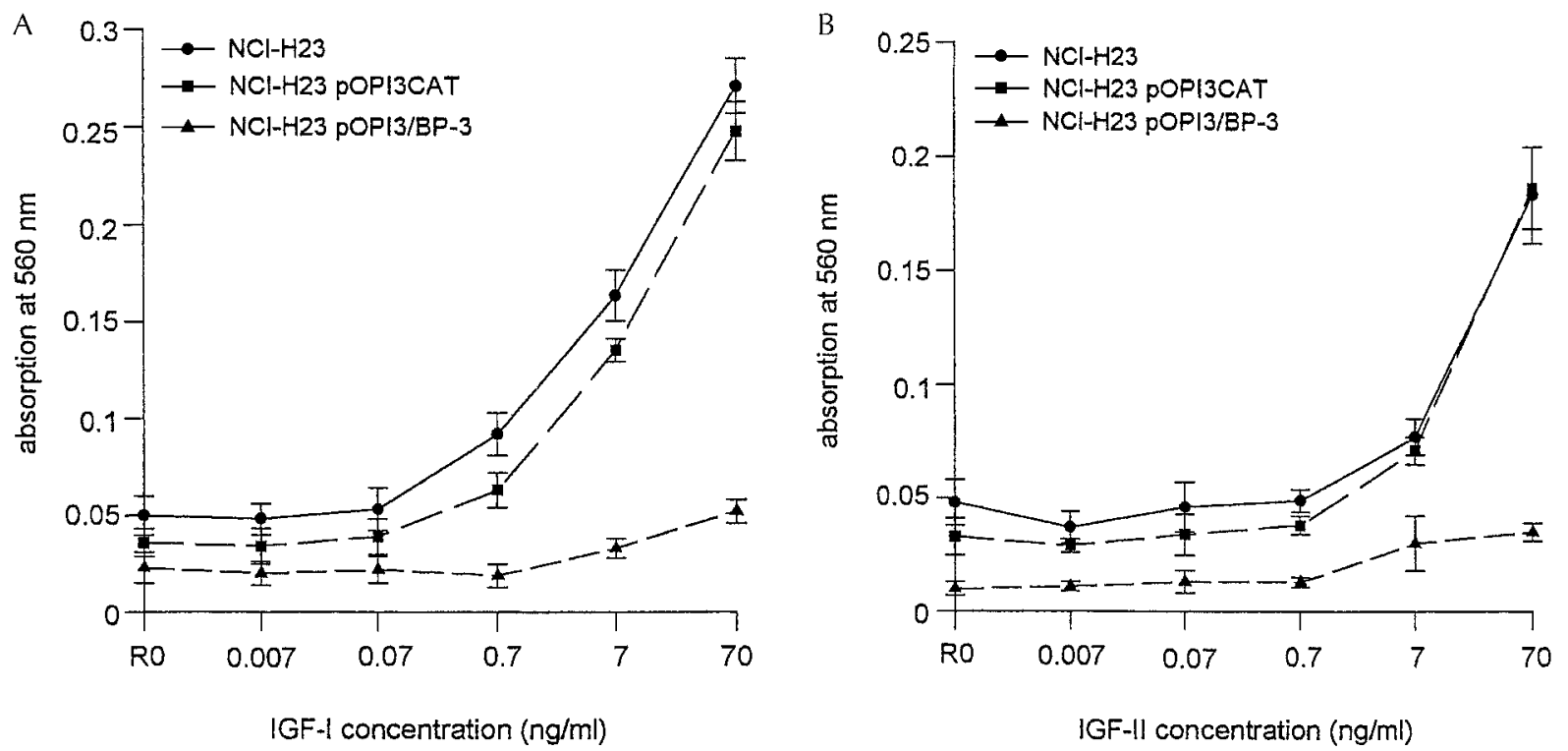

Figure 6 Effects of IGF-I and IGF-II on proliferation of NCl-H23, NCl-H23 pOPI3CAT and NCl-H23 pOPI3/BP-3; $1 \times 10^{4}$ cells were incubated with $0 \cdot 007-70 \mathrm{ng} / \mathrm{ml}$ IGF-I (A) or IGF-II (B) for 4 days in R0. The number of viable cells was calculated by the MTT assay. The values shown are means \pm S.D., calculated from replicates of eight. The growth of $\mathrm{NCl}-\mathrm{H} 23$ and NCl-H23 pOPI3CAT was stimulated by IGF-I and IGF-II in a dose-dependent manner. In contrast, the inhibition of proliferation in $\mathrm{NCl}-\mathrm{H} 23 \mathrm{pOPI} 3 / \mathrm{BP}-3 \mathrm{could}$ not be countered by treatment with either IGF-I or IGF-II.

It has previously been shown by ourselves and others that IGFs are mitogens for SCLC and NSCLC cell lines and that they can act in an autocrine/paracrine manner (Jaques et al. 1988, Reeve et al. 1992). The effects of IGFs are modulated by the family of IGFBPs (Baxter \& Martin 1989). Previous studies have demonstrated that IGFBP-3 can either stimulate or inhibit the mitogenic effects of IGF according to cell type (Elgin et al. 1987, Conover et al. 1990). Interestingly, growth inhibitory effects of IGFBP-3 have been identified which appear to function independently of IGF receptor signaling (Cohen et al. 1993, Oh et al. 1993, Lalou et al. 1996).

In this study we established an in vitro model to investigate the influence of IGFBP-3 on the growth of human lung cancer cells. We transfected the NSCLC cell line NCI-H23, which lacks IGFBP-3 expression, with IGFBP-3 cDNA in the eukaryotic expression vector pOPI3. As a control we also transfected the same cell line with the pOPI3CAT vector alone. Using RT-PCR screening with a vector-specific primer pair, we confirmed stably transfected single cell clones NCI-H23 pOPI3/ BP-3 and NCI-H23 pOPI3CAT. RT-PCR revealed marked expression of IGFBP-3 mRNA in NCI-H23 pOPI3/BP-3 in contrast to the parental cell line NCI$\mathrm{H} 23$ and the vector-transfected cell line NCI-H23 pOPI3CAT, in which no expression was detectable. We demonstrated IGFBP-3 protein secretion in CM by Western ligand blot and Western immunoblot. Both techniques showed large amounts of the characteristic $40-44 \mathrm{kDa}$ human IGFBP-3 protein in the IGFBP-3-transfected cell line but not in the control cell lines. The 26 and $36 \mathrm{kDa}$ bands detected in CMs of all cell lines by Western ligand blot might correspond to IGFBP-4 and IGFBP-2. These results are in agreement with observations of Noll et al. (1996), who demonstrated that all investigated NSCLC cell lines which expressed IGFBP-3 mRNA also secreted the protein into the CM. We quantified the secretion of IGFBP-3 using a specific ELISA and found a 20-fold increase of the protein in the IGFBP-3-transfected cell line. In NCI-H23 pOPI3/BP-3 we have established a cell line that expresses IGFBP-3 under the control of the RSV-LTR promoter. The amount of IGFBP-3 expressed and secreted into the $\mathrm{CM}$ was comparable with that of other IGFBP-3-expressing NSCLC cell lines.

Growth of NCI-H23 pOPI3/BP-3 in serumcontaining medium was dramatically slower than that of NCI-H23 and NCI-H23 pOPI3CAT, but confluence was reached at the same cell density. These results demonstrate a marked inhibitory effect of IGFBP-3 on proliferation but not on contact inhibition. Cohen et al. (1993) investigated the effects of IGFBP-3 transfection in a murine fibroblast cell line and also observed inhibitory effects on cell growth but confluence at lower cell density.

We investigated the influence of IGFBP-3 on the mitogenic effects of IGF-I and IGF-II on the cell lines in a serum-free medium MTT assay. Proliferation of NCI-H23 and NCI-H23 pOPI3CAT was stimulated by IGF-I and IGF-II in nanomolar concentrations in a 

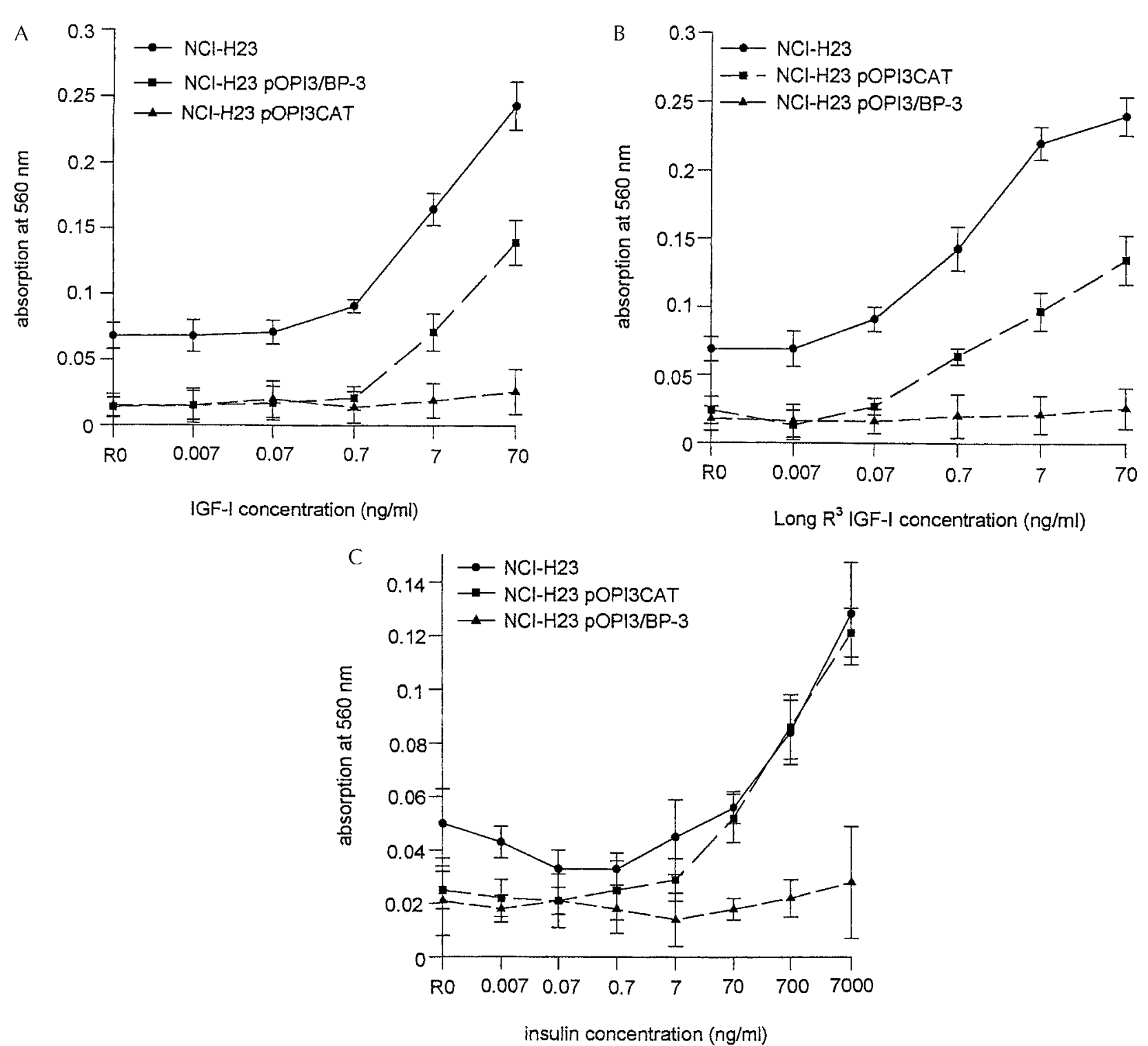

Figure 7 Effects of IGF-I, Long $\mathrm{R}^{3}$ IGF-I and insulin on proliferation of $\mathrm{NCl}-\mathrm{H} 23, \mathrm{NCl}-\mathrm{H} 23$ pOPI3CAT and NCl-H23 pOPI3/BP-3. Cells were incubated with 0.007-70 ng/ml IGF-I (A) or Long R ${ }^{3}$ IGF-I (B) or 0.007-7000 ng/ml insulin (C) for 4 days in serum-free R0 medium. The number of viable cells was calculated by the MTT assay. The values shown are means \pm S.D., calculated from replicates of eight. The data show that the IGF-I analog, Long R $^{3}$ IGF-I, which has full IGF-I receptor binding but only weak IGFBP-binding capacity, has no influence on the growth inhibitory effect in $\mathrm{NCl}-\mathrm{H} 23$ pOPI3/BP-3. The same observation was made after stimulation with insulin, which cannot bind IGFBPs but can bind to the IGF-I receptor. In contrast, both substances stimulate proliferation of $\mathrm{NCl}-\mathrm{H} 23$ and $\mathrm{NCl}-\mathrm{H} 23$ pOPI3CAT.

dose-dependent manner. In contrast, the slowed growth of the transfected cell line NCI-H23 pOPI3/BP-3 was not altered by treatment with IGFs. We observed that addition of IGF in equimolar concentrations or even in molar excess to NCI-H23 pOPI3/BP-3, did not influence the proliferation of this cell line significantly (addition of maximal $13 \mathrm{nM}$ IGF and $2 \times 10^{5} / \mathrm{ml}$ cell seed in view of the ELISA result indicating an IGFBP-3 concentration in CM of $1.3 \mathrm{nM}$ at $2.5 \times 10^{4} / \mathrm{ml}$ cell seeding). In the parental cell line NCI-H23 and in NCI-H23 pOPI3CAT a maximal mitogenic effect was observed at $7-10 \mathrm{nM}$ IGF-I or IGF-II.

Differing effects of exogenous IGFBP-3 and IGF-I have been described in various cell systems. Elgin et al. (1987) found addition of IGFBP-3 to stimulate growth of smooth muscle cells and fibroblasts, pre-exposed to IGF-I. Conover et al. (1990) observed a total inhibition of IGF-I/IGF-I receptor binding and IGF-I stimulation after 


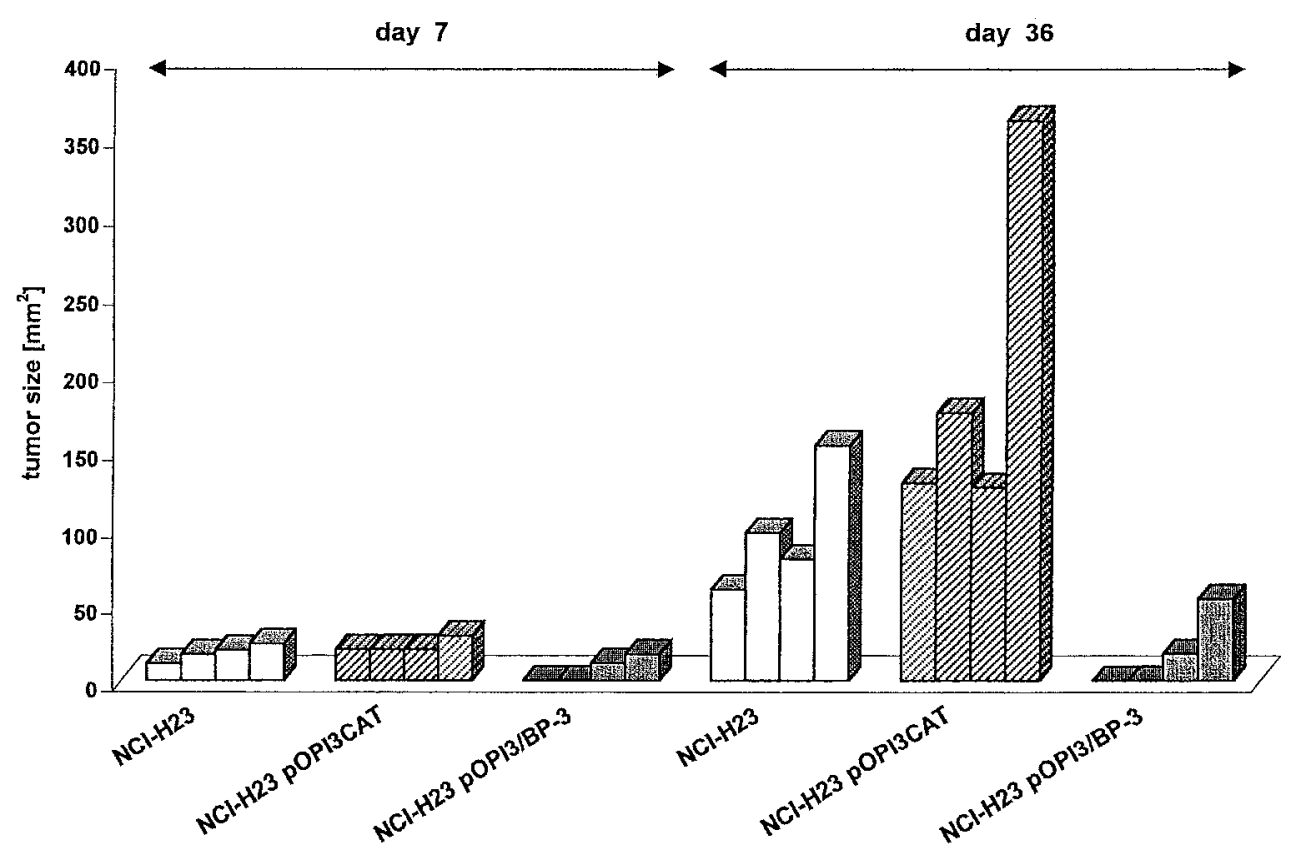

Figure 8 Xenotransplantation of $\mathrm{NCl}-\mathrm{H} 23, \mathrm{NCl}-\mathrm{H} 23$ pOPI3CAT and $\mathrm{NCl}-\mathrm{H} 23$ pOPI3/BP-3. For each cell line four nude mice were injected s.c.. Tumor sizes were measured every third day starting on day 7 . Values shown are tumor sizes in $\mathrm{mm}^{2}$ measured by calipers on days 7 and 36 . While animals inoculated with $\mathrm{NCl}-\mathrm{H} 23$ and $\mathrm{NCl}-\mathrm{H} 23$ pOPI3CAT developed large tumors, in mice injected with $\mathrm{NCl}-\mathrm{H} 23$ pOPI3/BP-3 no or minimal tumor growth was measured. This experiment was repeated twice.

coincubation of IGF-I with IGFBP-3 in equimolar concentrations. In breast cancer cells, addition of IGFBP-3 in molar excess inhibited IGF activities (Pratt \& Pollak 1994), while lower concentrations of IGFBP-3 relative to IGF-I, enhanced IGF action (Chen et al. 1994). One reason perhaps explaining the variation in these results might be the differing cell types used in these studies. The effects of IGF and IGFBP-3 may be regulated in different ways in these various cell systems. Furthermore, interpretation of the results is impaired by the different proliferation assays used. In any case, exogenous IGFBP-3 in an in vitro system cannot be assumed to reflect the effects of endogenous IGFBP-3 in vivo. In our study we have established an NSCLC cell line which itself expresses and secretes IGFBP-3, with the aim of obtaining a more accurate indication of the action of this binding protein in vivo in lung cancer.

In order to investigate whether IGFBP-3 exerts effects independently of IGF and its receptors we studied the growth behavior of NCI-H23, NCI-H23 pOPI3CAT and NCI-H23 pOPI3/BP-3 after the addition of an IGF-I analog, Long $\mathrm{R}^{3}$ IGF-I. This analog binds to the IGF-I receptor and mediates the mitogenic effect of IGF-I but shows poor binding to all known IGFBPs (Francis et al. 1992, Tomas et al. 1993). MTT assays revealed dose-dependent growth stimulation of the parental and vector-transfected cell lines, but no growth stimulation in the IGFBP-3-transfected cell line. Similar results were obtained after addition of insulin, which does not bind to any member of the IGFBP family, but can at high concentrations interact with the IGF-I receptor. These results are in agreement with studies from Cohen et al. (1993), who investigated the growth behavior of IGFBP-3-transfected Balb/c cells in the presence of insulin.

Our data suggest that endogenously produced IGFBP-3 inhibits cell growth of NCI-H23 pOPI3/BP-3 in an IGF/IGF-I receptor-independent manner. An IGFBP-3specific cell surface receptor, were it to exist, might explain such results. Other studies have also postulated the existence of such a receptor (Cohen et al. 1993, Oh et al. 1993, Lalou et al. 1996) and recently Leal et al. (1997) have shown the transforming growth factor (TGF) $-\beta$ receptor type V binds IGFBP-3. One could argue that IGFBP-3 may act via a nuclear pathway. The identification of a nuclear localization sequence in IGFBP-3 by Radulescu (1994) highlighted the possibility that this protein might exert the intracellular function of a nuclear tumor suppressor, similar to RB. Recently we were able to demonstrate nuclear localization of IGFBP-3 binding protein in the NSCLC cell line A549 (Jaques et al. 1997).

Furthermore, since the IGFBP-3 promoter contains an active response element for the tumor suppressor protein p53 and wild-type p53 can induce the expression of 
IGFBP-3 (Buckbinder et al. 1995), IGFBP-3 may mediate effects of p53 on cell cycle control or apoptosis. Thus, it was postulated that a novel autocrine/paracrine signaling pathway linking IGFBP-3 and p53 modulates functions of IGF such as cell growth, transformation and survival. Rajah et al. (1997) have shown, however, that IGFBP-3 can also induce apoptosis through a p53- and IGFindependent mechanism. In this study we could measure no induction of apoptosis in IGFBP-3-transfected cells by TUNEL assay under basal conditions. Further studies are warranted to investigate whether these cells are in a pre-apoptotic state or are growth arrested.

Bodner et al. (1992) and Mitsudomi et al. (1992) found p53 mutations in nearly all human lung cancer cell lines examined, including NCI-H23. This observation could explain why the parental cell line NCI-H23 does not express IGFBP-3. On the other hand we also showed strong IGFBP-3 expression and secretion in other NSCLC cell lines which do bear p53 mutations (Noll et al. 1996). An observation which is difficult to explain on the basis of our results showing a growth inhibitory effect of IGFBP-3, is the relatively high proliferation rate of NSCLC cells which do express IGFBP-3. This suggests that in such NSCLC cells the normal function of IGFBP-3 may be disrupted, for example by mutation in the IGFBP-3 gene itself or conversely in the putative IGFBP-3 receptor. Such genetic alterations might lead to relief of IGFBP-3 inhibitory effects and thus the rapid proliferation of such cell lines. The presence of IGFBP-3 mutations in NSCLC requires investigation.

Finally, we could show that nude mice injected with IGFBP-3-transfected cells either failed to develop tumors or developed only small tumors. In contrast, the injection of parental or vector-transfected cells always induced large tumors. These results suggest that IGFBP-3 overexpression decreases not only the mitogenic capacity in vitro but also the tumorigenic potential in vivo of NCI-H23. These data correlate with the recent observation by Damon et al. (1998) that overexpression of IGFBP-4 in the M12 prostate epithelial cell line has an inhibitory effect on proliferation.

In conclusion, our data suggest that the endogenous production and secretion of IGFBP-3 has inhibitory effects on the growth rate and tumorigenicity of lung cancer cells. The inhibition of cell proliferation could not be countered by the addition of IGF-I, IGF-II, Long $\mathrm{R}^{3}$ IGF-I or insulin, even in large amounts. Therefore, we speculate that IGFBP-3 may act in an IGF- and IGF-I receptorindependent manner.

Here we have created a cell culture model with which it is possible to study the function of IGFBP-3 in lung cancer cells. This in vitro model could be useful for further investigations focusing on potent inhibitors of cell growth which might mediate their effects via IGFBP-3. TGF- $\beta$ (Oh et al. 1995, Rajah et al. 1997), retinoic acid (Gucev et al. 1996), anti-estrogens (Huynh et al. 1996) and the tumor suppressor p53 (Buckbinder et al. 1995) all induce IGFBP-3.

Since the significance of IGFBP-3 localization (intracellular, nuclear or extracellular) for normal and tumor cell growth is yet not understood, further studies are required to clarify this issue. Our in vitro model may help to provide insight into the role of IGFBP-3 as a cancer cell growth inhibitor.

\section{Acknowledgements}

We thank Almut Wachtel, Cordula Löchelt and Heike Röder for excellent technical assistance and Alison Kraus for critically reading and correcting the manuscript. This work was supported by the Kind-Philipp-Stiftung of the Stifterverband für die Deutsche Wissenschaft.

\section{References}

Baxter RC 1988 Characterization of the acid-labile subunit of the growth hormone-dependent insulin-like growth factor binding protein complex. Journal of Clinical Endocrinology 2 1176-1185.

Baxter RC \& Martin JL 1989 Binding proteins for the insulin-like growth factors: structure, regulation and function. Progress in Growth Factor Research 1 49-68.

Bodner SM, Minna JD, Jensen SM, D'Amico D, Carbone D, Mitsudomi T, Fedorko J, Buchhagen DL, Nau MM, Gazdar AF \& Linnoila RI 1992 Expression of mutant p53 proteins in lung cancer correlates with the class of $\mathrm{p} 53$ gene mutation. Oncogene 7 743-749.

Buckbinder L, Talbott R, Velasco-Miguel S, Takenaka I, Faha B, Seizinger BR \& Kley N 1995 Induction of the growth inhibitor IGF-binding protein 3 by p53. Nature 377 646-649.

Chen JC, Shao ZM, Sheikh MS, Hussain A, LeRoith D, Roberts CT Jr \& Fontana JA 1994 Insulin-like growth factor-binding protein enhancement of insulin-like growth factor-I (IGF-I)-mediated DNA synthesis and IGF-I binding in human breast carcinoma cell line. Journal of Cellular Physiology 158 69-78.

Cohen P, Lamson PG, Okajima T \& Rosenfeld RG 1993 Transfection of the human insulin-like growth factor binding protein-3 gene into Balb/c fibroblasts inhibits cellular growth. Molecular Endocrinology 7 380-386.

Conover CA, Ronk M, Lombana F \& Powell DR 1990 Structural and biological characterization of bovine insulin-like growth factor binding protein-3. Endocrinology 127 2796-2803.

Damon SE, Maddison L, Ware JL \& Plymate SR 1998 Overexpression of an inhibitory insulin-like growth factor binding protein (IGFBP), IGFBP-4, delays onset of prostate tumor formation. Endocrinology 139 3456-3464.

Daughaday WH 1990 The possible autocrine/paracrine and endocrine roles of insulin-like growth factors of human tumors. Endocrinology $1271-4$.

Elgin RG, Busby WH Jr \& Clemmons DR 1987 An insulin-like growth factor (IGF) binding protein enhances the biological response to IGF-I. PNAS $\mathbf{8 4}$ 3254-3258.

Francis GL, Ross M, Ballard F, Milner SJ, McNeil KA, Wallace JC, King R \& Wells JR 1992 Novel recombinant fusion protein analogues of insulin-like growth factor (IGF)-I indicate the relative importance of IGF-binding protein and receptor binding for enhanced biological potency. Journal of Molecular Endocrinology 8 213-223.

Gazdar AF 1986 Advances in the biology of non small cell lung cancer. Chest $89277 \mathrm{~S}-283 \mathrm{~S}$. 
Gucev ZS, Oh Y, Kelley KM \& Rosenfeld RG 1996 Insulin-like growth factor binding protein 3 mediates retinoic acid- and transforming growth factor beta 2-induced growth inhibition in human breast cancer cells. Cancer Research 56 1545-1550.

Hossenlopp P, Seurin D, Segovia-Quinson B, Hardouin S \& Binoux GA 1986 Analysis of serum insulin-like growth factor binding proteins using Western blotting. Use of the method for titration of the binding proteins and competitive binding studies. Analytical Biochemistry 154 138-143.

Huynh H, Yang XF \& Pollak M 1996 Estradiol and antiestrogens regulate a growth inhibitory insulin-like growth factor binding protein 3 autocrine loop in human breast cancer cells. Journal of Biological Chemistry 271 1016-1021.

Jaques G, Rotsch M, Wegmann C, Worsch U, Maasberg M \& Havemann K 1988 Production of immunoreactive insulin-like growth factor-1 and response to exogenous IGF-I in small cell lung cancer cell lines. Experimental Cell Research 116 336-340.

Jaques G, Kiefer K, Schöneberger HJ, Wegmann B, Kaiser U, Brandscheid D \& Havemann K 1992 Differential expression of insulin-like growth factor binding proteins in human non-small cell lung cancer cell lines. European Journal of Cancer 28A 1899-1904.

Jaques G, Noll K, Wegmann B, Witten S, Kogan E, Radulescu RT \& Havemann K 1997 Nuclear localization of insulin-like growth factor binding protein 3 in a lung cancer cell line. Endocrinology 138 $1767-1770$

Kiefer P, Jaques G, Schöneberger J, Heinrich G \& Havemann K 1991 Insulin-like growth factor binding protein expression in human small cell lung cancer cell lines. Experimental Cell Research 192 414-417.

King GL, Kahn CR, Rechler MM \& Nissley SP 1980 Direct demonstration of separate receptors for growth activities of insulin and multiplication-stimulating activity (an insulin-like growth factor) using antibodies to the insulin receptor. Journal of Clinical Investigation 66 130-140

Krull FC, Jacobs S, Su YF, Svoboda ME, Van Wyk JJ \& Cuatrecasas P 1983 Monoclonal antibodies to receptors for insulin and somatomedin-C. Journal of Biological Chemistry 258 6561-6566.

Lalou C, Lassarre C \& Binoux M 1996 A proteolytic fragment of insulin-like growth factor (IGF) binding protein-3 that fails to bind IGFs inhibits the mitogenic effects of IGF-I and insulin. Endocrinology 137 3206-3212.

Leal SM, Liu Q, Huang SS \& Huang JS 1997 The type V transforming growth factor beta receptor is the putative insulin-like growth factor-binding protein 3 receptor. Journal of Biological Chemistry 272 20572-20576.

Mitsudomi T, Steinberg SM, Nau MM, Carbone D, D'Amico D, Bodner S, Oie HK, Linnoila RI, Mulshin JL, Minna JD \& Gazdar AF 1992 p53 gene mutations in small-cell lung cancer cell lines and their correlation with the presence of ras mutations and clinical features. Oncogene 7 171-180.

Nakanishi Y, Cuttitta F, Kasprzyk PG, Avis I, Steinberg SM, Gazdar AF \& Mulshine JL 1988 Growth factor effects on small cell lung cancer cells using a colorimetric assay: can a transferrin-like factor mediate autocrine growth? Experimental Cellular Biology 56 74-85.

Noll K, Wegmann BR, Havemann K \& Jaques G 1996 Insulin-like growth factors stimulate the release of insulin-like growth factor-binding protein-3 (IGFBP-3) and degradation of IGFBP-4 in nonsmall cell lung cancer cell lines. Journal of Clinical Endocrinology and Metabolism 81 2653-2662.

Oh Y, Müller HL, Lamson G \& Rosenfeld RG 1993 Insulin-like growth factor (IGF)-independent action of IGF-binding protein-3 in Hs578T human breast cancer cells. Journal of Biological Chemistry 268 14964-14971.

Oh Y, Müller HL, Ng L \& Rosenfeld RG 1995 Transforming growth factor- $\beta$-induced cell growth inhibition in human breast cancer cells is mediated through insulin-like growth factor-binding protein-3 action. Journal of Biological Chemistry 270 13589-13592.

Pratt SE \& Pollak MN 1994 Insulin-like growth factor-binding protein-3 (IGF-BP3) inhibits estrogen-stimulated breast cancer cell proliferation. Biochemical and Biophysical Research Communications 198 292-297.

Radulescu RT 1994 Nuclear localization signal in insulin-like growth factor-binding protein type 3. Trends in Biochemical Sciences 19278.

Rajah R, Valentinis B \& Cohen P 1997 Insulin-like growth factor (IGF)-binding protein-3 induces apoptosis and mediates the effects of transforming growth factor-beta1 on programmed cell death through a p53- and IGF-independent mechanism. Journal of Biological Chemistry 272 12181-12188.

Reeve J, Brinkman GA, Hughes S, Mitchell J, Schwander J \& Bleehen NM 1992 Expression of insulin-like growth factor (IGF) and IGF-binding protein genes in human lung tumor cell lines. Journal of the National Cancer Institute 84 628-634.

Shimasaki S \& Ling N 1991 Identification and molecular characterization of insulin-like growth factor binding proteins (IGFBP-1, -2, -3, -4, -5 and -6). Progress in Growth Factor Research 3 243-266.

Tomas FM, Knowles SE, Chandler CS, Francis GL, Owens PC \& Ballard FJ 1993 Anabolic effects of insulin-like growth factor-I (IGF-I) and an IGF-I variant in normal female rats. Journal of Endocrinology 137 413-421.

Wegmann BR, Schöneberger HJ, Kiefer PE, Jaques G, Brandscheid D \& Havemann K 1993 Molecular cloning of IGFBP-5 from SCLC cell lines and expression of IGFBP-4, IGFBP-5 and IGFBP-6 in lung cancer cell lines and primary tumors. European Journal of Cancer 29A 1578-1584.

Wraight CJ, Liepe IJ, White PJ, Hibbs AR \& Werther GA 1997 Intranuclear localization of insulin-like growth factor binding protein-3 (IGFBP-3) during cell division in human keratinocytes. Journal of Investigative Dermatology 111 239-242.

Received 23 December 1999

Accepted 26 April 2000 